\title{
A Practical Synthesis of Enantiopure 4,5-Dihydroisoxazole-5-carboxylic Acids
}

\author{
Abel Ros, ${ }^{\text {a }}$ Eleuterio Alvarez, ${ }^{\mathrm{a}}$ Hansjörg Dietrich, ${ }^{\mathrm{b}}$ Rosario Fernández, ${ }^{* \mathrm{c}}$ José M. Lassaletta*a \\ a Instituto de Investigaciones Químicas, CSIC-Use, c/ Américo Vespucio 49, Isla de la Cartuja, 41092 Seville, Spain \\ b Bayer CropScience GmbH, Industriepark Höchst G836, 65926 Frankfurt, Germany \\ c Departamento de Química Orgánica, Facultad de Química, Universidad de Sevilla, Apdo. de Correos 553, 41071 Seville, Spain \\ Fax +34(95)4460565; E-mail: jmlassa@iiq.csic.es \\ Received 7 September 2005
}

\begin{abstract}
The 1,3-dipolar cycloaddition of a variety of aromatic and aliphatic nitrile oxides to 2,5-trans-2,5-diphenylpyrrolidine derived acrylamide and cinnamamide efficiently affords the corresponding 4,5-dihydroisoxazole-5-carboxamides in a highly regioand stereoselective manner. The cycloaddition of aliphatic nitrile oxides to the analogue methacrylamide proceeds also smoothly to afford the expected cycloadducts in moderate yields and very high regio- and stereoselectivity. In sharp contrast, aromatic nitrile oxides react with the same amide to afford 5-methyl-4,5-dihydroisoxazole-5-carboxamides in higher yields but as near 1:1 mixtures of diastereoisomers. Acid hydrolysis of these products afforded enantiopure 4,5-dihydroisoxazole-5-carboxylic acids.
\end{abstract}

Key words: asymmetric synthesis, cycloadditions, heterocycles, nitrile oxides, isoxazolines

The 1,3-dipolar cycloaddition is a fundamental tool for the synthesis of a number of five-membered heterocyclic compounds. ${ }^{1}$ As a case of particular relevance, the 1,3-dipolar cycloaddition of nitrile oxides to alkenes provides a straightforward route to the 4,5-dihydroisoxazole ring, a structural motif in some biologically active compounds ${ }^{2}$ and a useful synthetic intermediate for the synthesis of a variety of bifunctional building blocks and bioactive compounds. ${ }^{1,3,4}$ There are a number of methodologies available for the stereochemical control of the reaction, ${ }^{5}$ most of them based on the use of chiral auxiliaries. Though the selective Lewis acid activation of the dipolarophiles in the presence of nitrile oxides and the amine bases required for its synthesis is particularly difficult, some catalytic approaches have also been reported. ${ }^{6}$ Nevertheless, there are still limitations in most cases regarding substrate generality (in particular for aliphatic substrates), chemical yields, regioselectivity and/or stereoselectivity. We now wish to report the results collected by using 2,5-trans-diphenylpyrrolidine as a suitable auxiliary in the stereo- and regioselective 1,3-dipolar cycloadditions of $\alpha, \beta$-unsaturated amides $\mathbf{1 a - c}$ with nitrile oxides.

The 2,5-trans-diphenylpyrrolidine, available in both enantiomeric forms from inexpensive starting materials, ${ }^{7}$ was chosen as a $C_{2}$-symmetric auxiliary in order to circumvent any consideration related to the conformational free rotation around the amide $\mathrm{C}-\mathrm{N}$ bond. Additionally,

SYNLETT 2005, No. 19, pp 2899-2904

Advanced online publication: 27.10.2005

DOI: 10.1055/s-2005-921894; Art ID: G27205ST

(c) Georg Thieme Verlag Stuttgart · New York the good diastereofacial differentiation observed in related contexts was also taken into account. ${ }^{8}$

$\alpha, \beta$-Unsaturated amides $\mathbf{1 a}$ and $\mathbf{1 b}$, readily available by acylation of $(S, S)$-2,5-diphenylpyrrolidine with acryloyl and cinnamoyl chlorides under standard conditions, were made to react with several nitrile oxides, obtained in situ from hydroximoyl chlorides $\mathbf{2 - 8}$ in the usual way ${ }^{9}$ (Scheme 1). The reaction proceeded smoothly in all cases to give the expected adducts 9-21 in variable yields. The results collected in Table 1 indicate the generality of the method, illustrated by cycloadditions of both amides $\mathbf{1 a}$ and $\mathbf{1 b}$ to aromatic (2-4, entries $1-5)$ and aliphatic (5-8, entries 6-13) substrates. In addition to the excellent diastereoselectivities observed in the generation of the new stereogenic centers at C-4 and C-5, it is worth mentioning that only trans-cycloadducts 10, 13, 15, 17, 19, and 21 were observed from cinnamoyl enamide $\mathbf{1 b}$, thereby excluding any epimerization of the products. Moreover, the reaction proved to be highly regioselective in all cases, a fact attributed to the repulsive steric interactions expected between the R group and the bulky 2,5-diphenylpyrrolidine moiety in the opposite regioisomer.

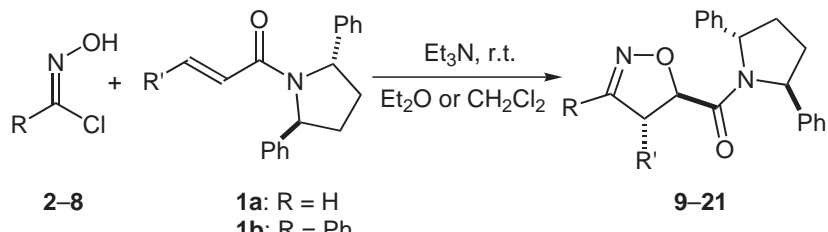

Scheme 1 1,3-Dipolar cycloaddition of $\alpha, \beta$-unsaturated amides 1a,b.

The more challenging extension of this methodology for the synthesis of products bearing quaternary stereogenic centers at C-5 was also investigated by reacting substrates 2-5 and $\mathbf{8}$ with methacrylamide 1c as the dipolarophile (Scheme 2, Table 1, entries 14-18).

In this case, a different behavior for aliphatic and aromatic substrates was observed: the former (e.g., 5 or $\mathbf{8}$ ) reacted slowly to afford products $\mathbf{2 5}$ and $\mathbf{2 6}$ in moderate yields, but with complete regio- and diastereoselectivity (entries 17 and 18). In sharp contrast, aromatic substrates 2-4 react faster to afford cycloadducts 22-24 in higher yields and with high regioselectivity, but with negligible de (entries 14-16). A retro-cyclization path leading to a thermodynamically controlled product distribution was 
<smiles>[R]C(=O)ON=C([R5])Cl</smiles>

(R)-22-26
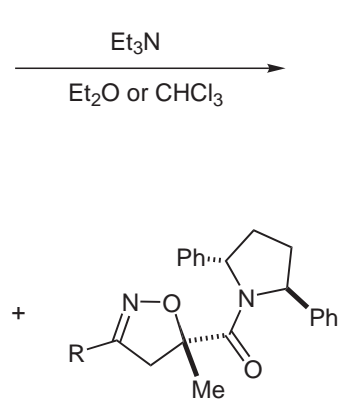

(S)-22-24
Scheme 2 1,3-Dipolar cycloadditions of methacrylamide 1c.

experimentally discarded: pure $(R)$ - and $(S)$-22 cycloadducts were heated separately under the reaction conditions without any perceptible epimerizations.

Reductive release of the chiral auxiliary by reagents such as $\mathrm{LiEt}_{3} \mathrm{BH}$ (amide to alcohol) ${ }^{10}$ or the Schwartz reagent (amide to aldehyde) ${ }^{11}$ failed in our case. Hydrolysis by $\mathrm{HCl}-\mathrm{AcOH}$, however, afforded the desired 4,5-dihydroisoxazole-5-carboxylic acids 27-30 (Scheme 3).

The absolute $R, R$ configuration of the newly created stereogenic centers in cycloadduct $\mathbf{1 0}$ was determined by single-crystal X-ray diffraction analysis ${ }^{12}$ (Figure 1), while that of $(R)-\mathbf{2 7},(R)-\mathbf{3 0}$ and the parent cycloadducts $(R)-9$ and $(R)-22$ were deduced after comparison of the optical rotation of the former with literature data. Thus,

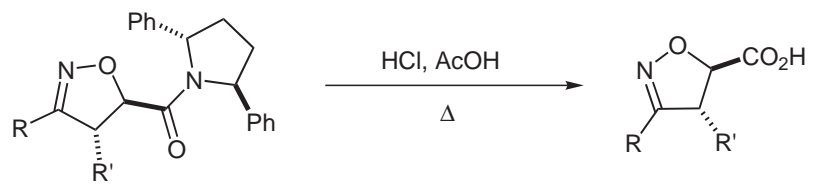

(R)-9: $\mathrm{R}=\mathrm{Ph} ; \mathrm{R}^{\prime}=\mathrm{H}$

(R)-16: $\mathrm{R}=i$-Bu; $\mathrm{R}^{\prime}=\mathrm{H}$

$(R, R)-10: \mathrm{R}=\mathrm{R}^{\prime}=\mathrm{Ph}$

(R)-27: $\mathrm{R}=\mathrm{Ph} ; \mathrm{R}^{\prime}=\mathrm{H}, 80 \%$ (R)-28: $\mathrm{R}=i$-Bu; $\mathrm{R}^{\prime}=\mathrm{H}, 73 \%$ $(R, R)-29: \mathrm{R}=\mathrm{R}^{\prime}=\mathrm{Ph}, 60 \%$<smiles>C[C@]1(C(=O)N2C(c3ccccc3)CC[C@H]2c2ccccc2)CC(c2ccccc2)=NO1</smiles>

(R)-22

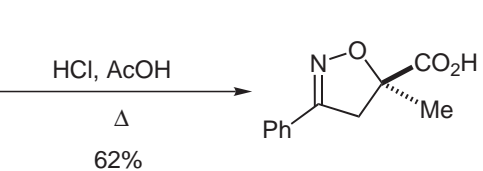

(R)-30

Scheme 3 Release of the chiral auxiliary.

compound $(R)-27$ had $[\alpha]_{\mathrm{D}}^{22}-194(c 0.5, \mathrm{MeOH})$ and this value was compared with reported data for $(R)$-27 (sample of ee $=68 \%$ : $\left.[\alpha]_{\mathrm{D}}{ }^{20}-116\right)^{13}$ and $(S)-27$ (sample of ee $=60 \%:[\alpha]_{\mathrm{D}}+67\left(c 0.4, \mathrm{CHCl}_{3}\right) .{ }^{14}$ Additionally, compound $(R)-30$ had $[\alpha]_{\mathrm{D}}{ }^{20}-131(c 0.14, \mathrm{MeOH})$ and the optical rotation was compared with reported data for $(S)$ 30 (sample of ee $=75 \%$ : $[\alpha]_{\mathrm{D}}{ }^{20}+109$ ). ${ }^{13}$ Assuming uniform reaction pathways for the cycloadditions of 2-8 to cinnamamide $\mathbf{1 b}$ and acrylamide $\mathbf{1 a}$, the $R$ configuration of $11,12,14,16,18$, and 20 and the $R, R$ configuration of 13, 15, 17, 19, and 21 were assigned by analogy with 9 and $\mathbf{1 0}$, respectively.

Table 1 1,3-Dipolar Cycloaddition of Nitrile Oxides 2-8 to Amides 1a-c: Synthesis of Isoxazolines 9-26

\begin{tabular}{|c|c|c|c|c|c|c|c|c|}
\hline Entry & $\begin{array}{l}\text { Sub- } \\
\text { strate }\end{array}$ & $\mathrm{R}$ & Amide & Solvent & Product & Time $^{\mathrm{a}}$ & $\begin{array}{l}\text { Yield } \\
(\%)^{\mathrm{b}}\end{array}$ & $\operatorname{de}(\%)^{\mathrm{c}}$ \\
\hline 1 & 2 & $\mathrm{Ph}$ & $1 \mathbf{a}$ & $\mathrm{Et}_{2} \mathrm{O}$ & 9 & $1 \mathrm{~h}$ & 98 & $>99$ \\
\hline 2 & 2 & $\mathrm{Ph}$ & $1 \mathrm{~b}$ & $\mathrm{Et}_{2} \mathrm{O}$ & 10 & $48 \mathrm{~h}$ & $50(18)$ & $>99$ \\
\hline 3 & 3 & & $1 \mathbf{a}$ & $\mathrm{Et}_{2} \mathrm{O}$ & 11 & $1 \mathrm{~h}$ & 90 & $>99$ \\
\hline 4 & 4 & & $1 \mathrm{a}$ & $\mathrm{Et}_{2} \mathrm{O}$ & $\mathrm{MeC}$ & $1 \mathrm{~h}$ & 95 & $>99$ \\
\hline
\end{tabular}


Table 1 1,3-Dipolar Cycloaddition of Nitrile Oxides 2-8 to Amides 1a-c: Synthesis of Isoxazolines 9-26 (continued)

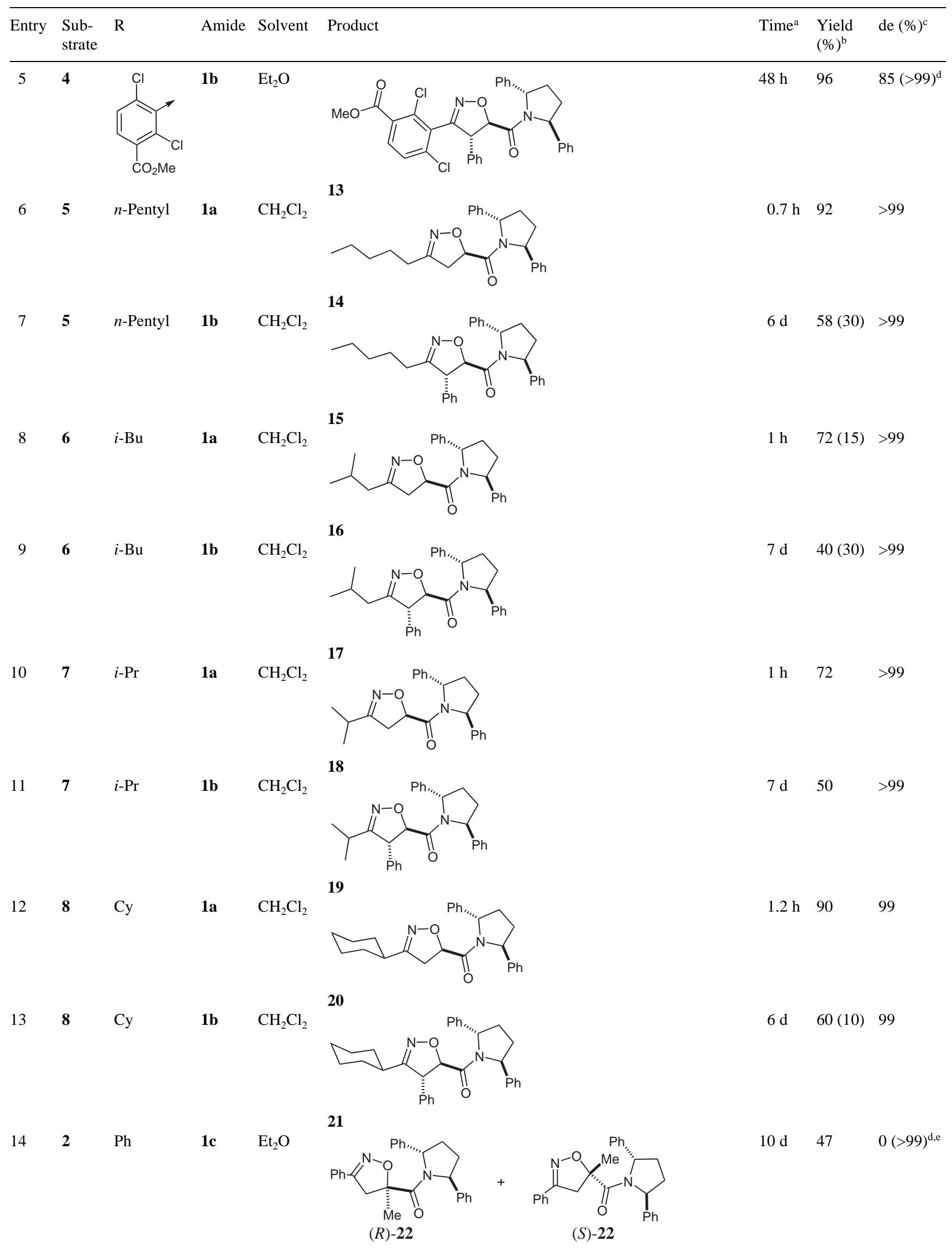


Table 1 1,3-Dipolar Cycloaddition of Nitrile Oxides 2-8 to Amides 1a-c: Synthesis of Isoxazolines 9-26 (continued)

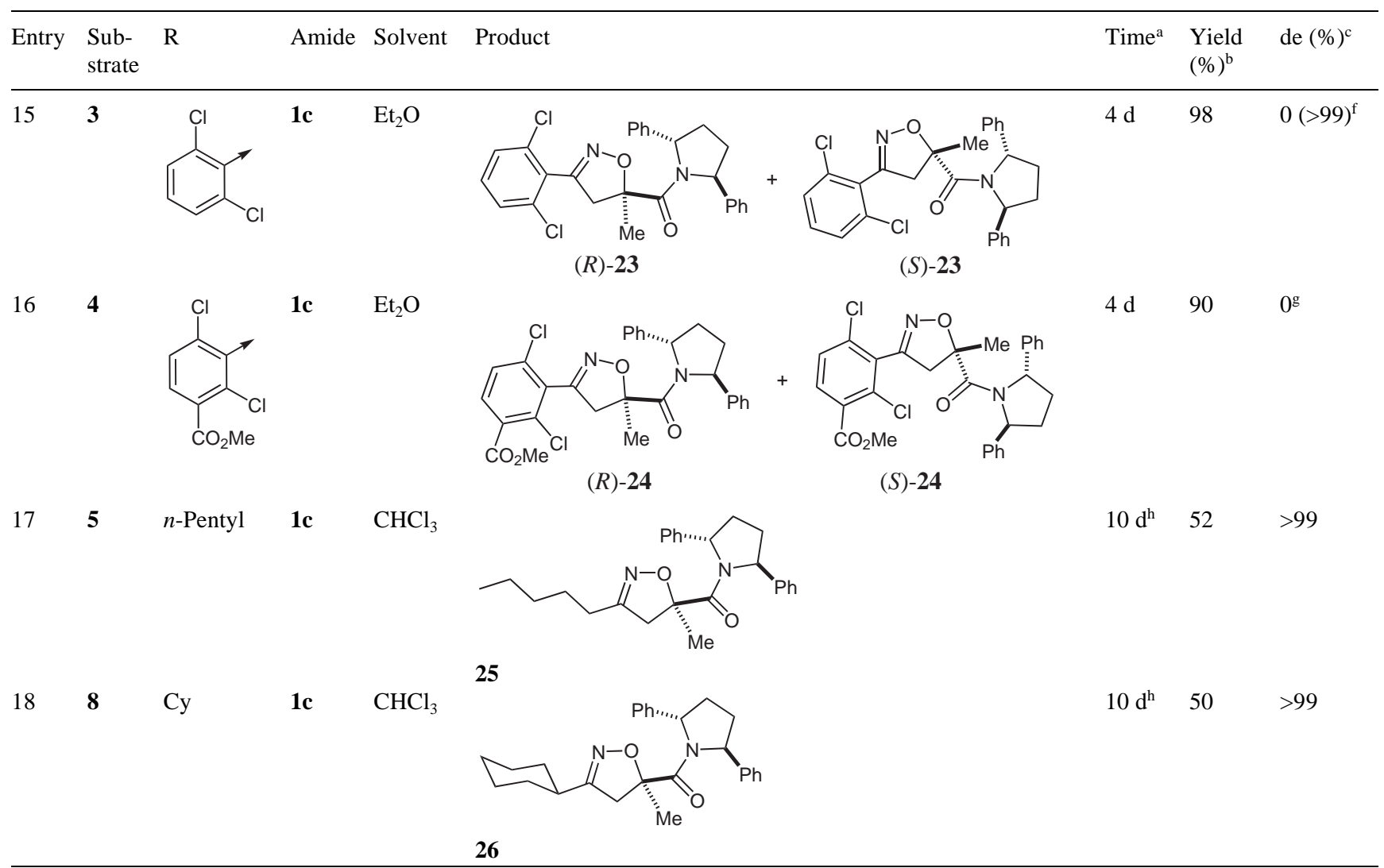

${ }^{a}$ For reactions performed at r.t. unless indicated otherwise.

${ }^{\mathrm{b}}$ Yield of isolated product. In parenthesis: yield of recovered, unreacted amide $\mathbf{1 .}$

${ }^{\mathrm{c}}$ Determined by ${ }^{1} \mathrm{H}$ NMR and ${ }^{13} \mathrm{C}$ NMR analysis of the crude reaction mixtures.

${ }^{\mathrm{d}}$ After column chromatography.

e The absolute configurations of $(R)$ - and $(S)$-22 were assigned tentatively by analogy of their characterization data with $(R)$ - and $(S)$-23.

${ }^{\mathrm{f}}$ Pure $(S)-\mathbf{2 3}$ was obtained by fractional crystallization.

${ }^{\mathrm{g}}$ Inseparable mixture of diastereomers.

${ }^{\text {h }}$ Performed at $55^{\circ} \mathrm{C}$.

The absolute configuration of $(S)$-23 was also determined by single-crystal X-ray diffraction ${ }^{15}$ (Figure 2), while those of $(R)$ - and $(S)$-22 were assigned tentatively by analogy of their characterization data with $(R)$ - and $(S)$ 23.

The high inductions observed for the cycloadditions of nitrile oxides to $\mathbf{1 a}$ and $\mathbf{1 b}$ and the absolute configurations at C-4 and C-5 can be explained as the result of the shielding of the si face of the $\mathrm{C}=\mathrm{C}$ double bond of the dipolarophile by the neighbour phenyl group in the pyrrolidine moiety in the preferred s-cis conformation (Figure 3). Such a difference is anticipated in view of the higher steric $\mathrm{CH}(\beta)$-auxiliary interactions in the s-trans conformer.

Apparently, the high inductions and the absolute configurations of the products $\mathbf{2 5}$ and $\mathbf{2 6}$ of the cycloadditions of aliphatic nitrile oxides to $1 \mathrm{c}$ are also consistent with a similar analysis, but in this case the preference for the $s$ cis conformer is not clear in view of the similar steric interactions that arise from $\mathrm{C}(\beta) \mathrm{H}_{2}$-auxiliary or $\mathrm{CH}_{3}$-aux-

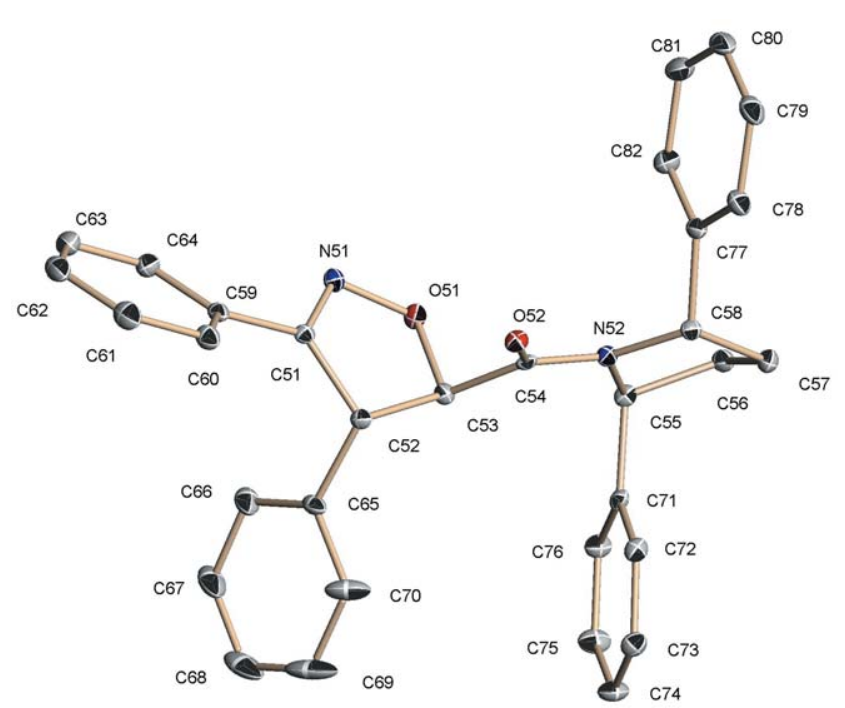

Figure 1 Crystal structure of $(R, R)-\mathbf{1 0}$. $\mathrm{H}$ atoms omitted for clarity. 


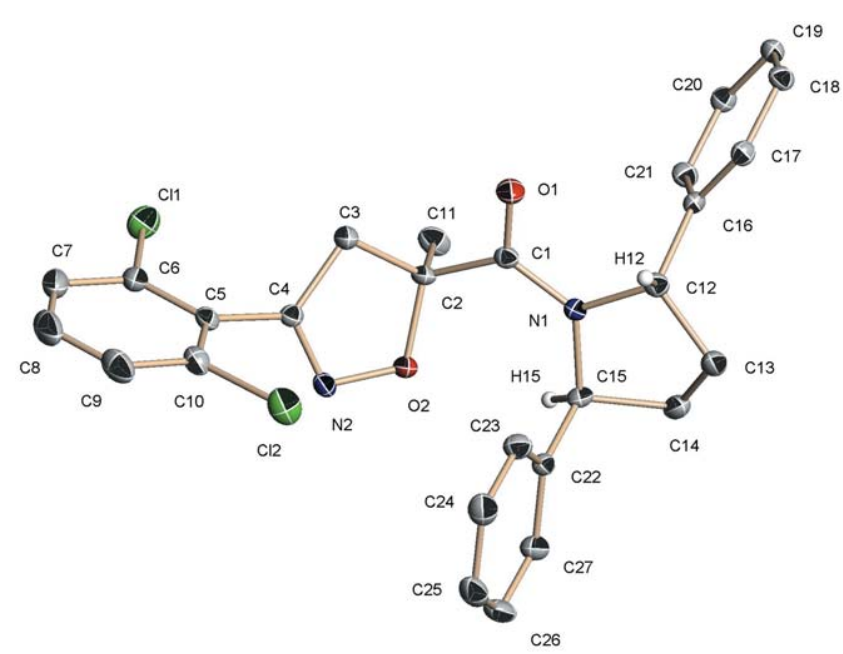

Figure 2 Crystal structure of $(S)-\mathbf{2 3}$. H atoms omitted for clarity.

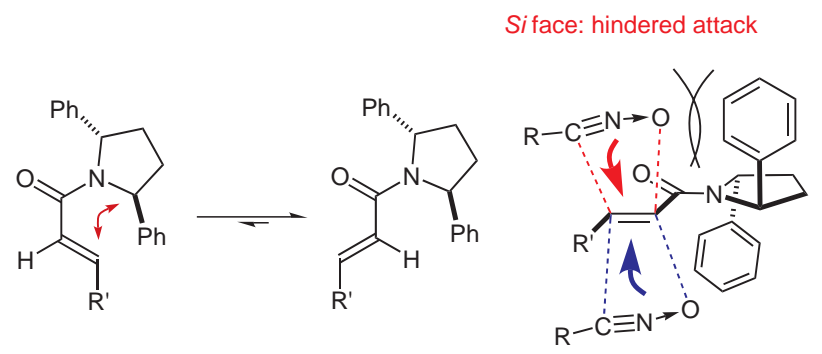

Re face: favored attack

Figure 3

In conclusion, the excellent facial discrimination by the 2,5-diphenylpyrrolidine makes it a convenient auxiliary which very efficiently controls the stereochemical course of the cycloaddition reactions of amides $\mathbf{1 a}, \mathbf{b}$ with nitrile oxides, affording single diastereomers in practically all cases. A limited success was encountered in the extension of the methodology for the synthesis of cycloadducts containing stereogenic centers: the cycloadditions to methacrylamide 1c are substrate-dependent and proceed with high selectivity for aliphatic substrates only.

Hydroximoyl chlorides $2-\mathbf{8}^{16}$ and amides $1 \mathbf{a}^{17}$ and $\mathbf{1} \mathbf{c}^{8 \mathrm{~b}}$ were synthesized according to literature procedures. Compound $\mathbf{1 b}$ was synthesized by acylation of $(S, S)$-2,5-diphenyl-pyrrolidine with cinnamoyl chloride under standard conditions: $[\alpha]_{\mathrm{D}}{ }^{20}-209.3\left(c 0.73, \mathrm{CHCl}_{3}\right.$ ). ${ }^{1} \mathrm{H}$ NMR $\left(300 \mathrm{MHz}, \mathrm{CDCl}_{3}\right): \delta=1.71(\mathrm{dd}, 1 \mathrm{H}, J=12.0 \mathrm{~Hz}, J=5.7$ $\mathrm{Hz}), 1.79(\mathrm{dd}, 1 \mathrm{H}, J=12.0 \mathrm{~Hz}, J=5.7 \mathrm{~Hz}), 2.36(\mathrm{~m}, 1 \mathrm{H}), 2.50(\mathrm{~m}$, $1 \mathrm{H}), 5.40(\mathrm{~d}, 1 \mathrm{H}, J=8.1 \mathrm{~Hz}), 5.56(\mathrm{~d}, 1 \mathrm{H}, J=8.1 \mathrm{~Hz}), 6.42(\mathrm{~d}, 1$ $\mathrm{H}, J=15.3 \mathrm{~Hz}), 7.16-7.31(\mathrm{~m}, 15 \mathrm{H}), 7.49(\mathrm{~d}, 1 \mathrm{H}, J=15.3 \mathrm{~Hz}) .{ }^{13} \mathrm{C}$ NMR $\left(75 \mathrm{MHz}, \mathrm{CDCl}_{3}\right): \delta=30.0,32.6,61.7,61.9,118.7,124.8$, 124.9, 126.2, 127.0, 127.3, 128.0, 128.1, 128.4, 129, 134.6, 141.7, $142.4,143.4,164.8$. MS (EI): $m / z$ (rel. intensity) $=354(100)\left[\mathrm{M}^{+}+\right.$ 1], $353(65)\left[\mathrm{M}^{+}\right], 249(35)$. HRMS: $\mathrm{m} / z$ calcd for $\mathrm{C}_{25} \mathrm{H}_{24} \mathrm{NO}$ : 354.1858; found: 354.1846 .

Synthesis of 3-Alkyl-5-formyl-4,5-dihydroisoxazoles (9-25) Method A

$\mathrm{Et}_{3} \mathrm{~N}(1.1 \mathrm{mmol}, 159 \mu \mathrm{L})$ was added dropwise to a solution of amide 1a-c (1 mmol) and hydroximoyl chloride $2-4(1.1 \mathrm{mmol})$ in $\mathrm{Et}_{2} \mathrm{O}$
$(10 \mathrm{~mL})$. The mixture was stirred at r.t. and monitored by TLC. Brine $(10 \mathrm{~mL})$ was added and the aqueous layer was extracted with $\mathrm{Et}_{2} \mathrm{O}(3 \times 15 \mathrm{~mL})$. The organic layer was dried $\left(\mathrm{Na}_{2} \mathrm{SO}_{4}\right)$, concentrated, and the residue was purified by flash chromatography.

\section{Method B}

$\mathrm{Et}_{3} \mathrm{~N}(0.66 \mathrm{mmol}, 95 \mu \mathrm{L})$ was added dropwise to a solution of amide $\mathbf{1 a}-\mathbf{c}(0.22 \mathrm{mmol})$ and hydroximoyl chloride $\mathbf{5 - 8}(0.66 \mathrm{mmol})$ in $\mathrm{CH}_{2} \mathrm{Cl}_{2}(10 \mathrm{~mL})$. The mixture was treated as in method $\mathrm{A}$.

\section{Selected Data}

Compound 9: $\mathrm{mp} 80-82{ }^{\circ} \mathrm{C} ;[\alpha]_{\mathrm{D}}{ }^{20}-379\left(c 1.09, \mathrm{CHCl}_{3}\right) .{ }^{1} \mathrm{H}$ NMR $\left(500 \mathrm{MHz}, \mathrm{CDCl}_{3}\right): \delta=1.77(\mathrm{dd}, 1 \mathrm{H}, J=12.5 \mathrm{~Hz}, J=6.5 \mathrm{~Hz}), 1.82$ $(\mathrm{dd}, 1 \mathrm{H}, J=12.0 \mathrm{~Hz}, J=6.0 \mathrm{~Hz}), 2.43(\mathrm{~m}, 1 \mathrm{H}), 2.58(\mathrm{~m}, 1 \mathrm{H}), 3.03$ $(\mathrm{dd}, 1 \mathrm{H}, J=17.0 \mathrm{~Hz}, J=11.0 \mathrm{~Hz}), 4.01(\mathrm{dd}, 1 \mathrm{H}, J=17.0 \mathrm{~Hz}$, $J=7.5 \mathrm{~Hz}), 4.83(\mathrm{dd}, 1 \mathrm{H}, J=11.0 \mathrm{~Hz}, J=7.5 \mathrm{~Hz}), 5.55(\mathrm{~d}, 1 \mathrm{H}$, $J=8.5 \mathrm{~Hz}), 5.84(\mathrm{~d}, 1 \mathrm{H}, J=8.0 \mathrm{~Hz}), 7.17-7.38(\mathrm{~m}, 15 \mathrm{H}) .{ }^{13} \mathrm{C}$ NMR (125 MHz, $\mathrm{CDCl}_{3}$ ): $\delta=30.5,32.9,36.2,61.9,62.6,79.0$, 125.1, 125.6, 125.8, 126.9, 127.6, 128.6, 128.9, 129.0, 130.2, 142.2, 143.4, 157.3, 167.1. MS (EI): $\mathrm{m} / z$ (rel. intensity) $=396(13)\left[\mathrm{M}^{+}\right]$, 365 (47), 91 (100). HRMS: $m / z$ calcd for $\mathrm{C}_{26} \mathrm{H}_{24} \mathrm{~N}_{2} \mathrm{O}_{2}: 396.1838$; found: 396.1828 .

Compound 19: $[\alpha]_{\mathrm{D}}{ }^{20}-424\left(c 0.87, \mathrm{CHCl}_{3}\right) .{ }^{1} \mathrm{H}$ NMR $(400 \mathrm{MHz}$, $\left.\mathrm{CDCl}_{3}\right): \delta=0.93(\mathrm{~d}, 3 \mathrm{H}, J=7.0 \mathrm{~Hz}), 1.07(\mathrm{~d}, 3 \mathrm{H}, J=7.0 \mathrm{~Hz}), 1.73$ $(\mathrm{dd}, 1 \mathrm{H}, J=12.5 \mathrm{~Hz}, J=6.4 \mathrm{~Hz}), 1.78(\mathrm{dd}, 1 \mathrm{H}, J=12.5 \mathrm{~Hz}$, $J=6.4 \mathrm{~Hz}), 2.30(\mathrm{~m}, 1 \mathrm{H}), 2.34(\mathrm{~m}, 1 \mathrm{H}), 2.52-2.54(\mathrm{~m}, 1 \mathrm{H}), 4.48$ $(\mathrm{d}, 1 \mathrm{H}, J=6.8 \mathrm{~Hz}), 4.94(\mathrm{~d}, 1 \mathrm{H}, J=6.8 \mathrm{~Hz}), 5.49(\mathrm{~d}, 1 \mathrm{H}, J=8.4$ $\mathrm{Hz}), 5.78(\mathrm{~d}, 1 \mathrm{H}, J=8.0 \mathrm{~Hz}), 6.91-7.30(\mathrm{~m}, 15 \mathrm{H}) .{ }^{13} \mathrm{C}$ NMR $(100$ $\left.\mathrm{MHz}, \mathrm{CDCl}_{3}\right): \delta=19.5,20.4,26.9,30.4,32.9,57.0,61.9,62.6$, $86.2,125.2,125.4,126.9,127.3,127.5,128.0,128.6,128.8,128.9$, 137.3, 142.3, 143.2, 166.4, 167.6. MS (EI): $\mathrm{m} / \mathrm{z}$ (rel. intensity) $=438$ (14) $\left[\mathrm{M}^{+}\right], 188$ (71), 91 (100). Anal. Calcd for $\mathrm{C}_{29} \mathrm{H}_{30} \mathrm{~N}_{2} \mathrm{O}_{2}$ : C, 79.42; H, 6.89; N, 6.39. Found: C, 79.52; H, 6.75; N, 6.05.

\section{Synthesis of Compound 27}

To a solution of 9 (395 mg, $1 \mathrm{mmol})$ in $\mathrm{AcOH}(4 \mathrm{~mL})$ was added 6 $\mathrm{N} \mathrm{HCl}(2 \mathrm{~mL})$ and the mixture was stirred at $100{ }^{\circ} \mathrm{C}$ for $40 \mathrm{~h}$. The mixture was then co-evaporated several times with toluene and the residue was purified by flash chromatography (24:1 EtOAc-AcOH) yielding $153 \mathrm{mg}(80 \%)$ of 27 as a white semi-solid: $[\alpha]_{\mathrm{D}}{ }^{20}-194(c$ $0.45, \mathrm{MeOH}) \quad\left\{\right.$ lit. $^{14}\left(80: 20 \mathrm{~S} / \mathrm{R}\right.$ mixture): $[\alpha]_{\mathrm{D}}{ }^{20}+67$ (c 0.41 , $\left.\left.\mathrm{CHCl}_{3}\right)\right\} .{ }^{1} \mathrm{H}$ NMR (300 MHz, MeOD): $\delta=3.58(\mathrm{dd}, 1 \mathrm{H}, J=17.1$ $\mathrm{Hz}, J=6.9 \mathrm{~Hz}), 3.71(\mathrm{dd}, 1 \mathrm{H}, J=17.1 \mathrm{~Hz}, J=11.7 \mathrm{~Hz}), 5.13(\mathrm{dd}$, $1 \mathrm{H}, J=11.4 \mathrm{~Hz}, J=6.9 \mathrm{~Hz}), 7.36-7.65(\mathrm{~m}, 5 \mathrm{H}) .{ }^{13} \mathrm{C} \mathrm{NMR}(75$ MHz, MeOD): $\delta=39.9,79.4,128.0,129.9,130.1,131.6,157.9$, 174.0. MS (EI): $m / z$ (rel. intensity) $=191(46)\left[\mathrm{M}^{+}\right], 146(100), 118$ (71), 77 (93). Anal. Calcd for $\mathrm{C}_{10} \mathrm{H}_{9} \mathrm{NO}_{3}: \mathrm{C}, 62.82 ; \mathrm{H}, 4.74 ; \mathrm{N}, 7.33$. Found: C, 62.62; H, 4.92; N, 7.28.

Compound 30: $(R)-\mathbf{2 2}$ was hydrolysed as described for $\mathbf{2 7}$ and purified by flash chromatography (30:1 EtOAc-AcOH) to afford 30 $(62 \%)$ as a syrup: $[\alpha]_{\mathrm{D}}{ }^{20}-131(c 0.14, \mathrm{MeOH}) .{ }^{1} \mathrm{H} \mathrm{NMR}(500 \mathrm{MHz}$, $\left.\mathrm{CDCl}_{3}\right): \delta=1.76(\mathrm{~s}, 3 \mathrm{H}), 3.28(\mathrm{~d}, 1 \mathrm{H}, J=17.0 \mathrm{~Hz}), 3.87(\mathrm{~d}, 1 \mathrm{H}$, $J=17.0 \mathrm{~Hz}), 7.24-7.63(\mathrm{~m}, 5 \mathrm{H}) .{ }^{13} \mathrm{C} \mathrm{NMR}\left(125 \mathrm{MHz}, \mathrm{CDCl}_{3}\right)$ : $\delta=23.3,45.1,85.9,126.9,128.5,128.9,130.8,157.2,175.9 . \mathrm{MS}$ $(\mathrm{EI}): m / z$ (rel. intensity) $=206(17)\left[\mathrm{M}^{+}+1\right], 160(91), 123(100)$. HRMS: $m / z$ calcd for $\mathrm{C}_{11} \mathrm{H}_{12} \mathrm{NO}_{3}: 206.0817$; found: 206.0807.

\section{Acknowledgment}

We thank the Spanish 'Ministerio de Ciencia y Tecnología' (grant CTQ2004-00290 and CTQ2004-00241) and the 'Junta de Andalucía' for financial support. A.R. thanks Bayer CropScience for a predoctoral fellowship and the donation of chemicals. 


\section{References}

(1) (a) 1,3-Dipolar Cycloaddition Chemistry; Padwa, A., Ed.; Wiley: New York, 1984. (b) Torssell, K. B. G. Nitrile Oxides, Nitrones and Nitronates in Organic Synthesis; VCH: Weinheim, 1988. (c) Curran, D. P. Advances in Cycloaddition; JAI: Greenwich, CN, 1988.

(d) Cycloaddition Reactions in Organic Synthesis; Kobayashi, S.; Jørgensen, K. A., Eds.; Wiley-VCH: Weinheim, 2002.

(2) Pirrung, M. C.; Tumey, L. N.; Raetz, C. R. H.; Jackman, J. E.; Snehalatha, K.; McLerren, A. L.; Fierke, C. A.; Gantt, S. L.; Rusche, C. M. J. Med. Chem. 2002, 45, 4359.

(3) (a) Kozikowski, A. P. Acc. Chem. Res. 1984, 17, 410. (b) Kanemasa, S.; Tsuge, O. Heterocycles 1990, 30, 719.

(4) Selected recent reports: (a) Fuller, A. A.; Chen, B.; Minter, A. R.; Mapp, A. K. J. Am. Chem. Soc. 2005, 127, 5376. (b) Bode, J. W.; Fraefel, N.; Muri, D.; Carreira, E. M. Angew. Chem. Int. Ed. 2001, 40, 2082.

(5) Review: (a) Gothelf, K. V.; Jørgensen, K. A. Chem. Rev. 1998, 98, 863. Recent examples: (b) Tamai, T.; Asano, S.; Totani, K.; Takao, K.-i.; Tadano, K.-i. Synlett 2003, 1865. (c) Faita, G.; Paio, A.; Quadrelli, P.; Rancati, F.; Seneci, P. Tetrahedron 2001, 57, 8313. (d) Yamamoto H., Watanabe S., Kadotani K., Hasegawa M., Noguchi M., Kanemasa S.; Tetrahedron Lett.; 2000, 41: 3131. (e) Curran, D. P.; Yoon, M.-H. Tetrahedron 1997, 53, 1971. (f) Oppolzer, W.; Kingma, A. J.; Pillai, S. K. Tetrahedron Lett. 1991, 4893. (g) Akiyama, T.; Okada, K.; Ozaki, S. Tetrahedron Lett. 1992, 5763. (h) Rispens, M. T.; Keller, E.; De Lange, B.; Zijlstra, R. W. J.; Feringa, B. L. Tetrahedron: Asymmetry 1994, 5, 607.

(6) (a) Sibi, M. P.; Itoh, K.; Jasperse, C. P. J. Am. Chem. Soc. 2004, 126, 5366. (b) Shimizu, M.; Ukaji, Y.; Inomata, K. Chem. Lett. 1996, 455.

(7) (a) Chong, J. M.; Clarke, I. S.; Koch, I.; Olbach, P. C.; Taylor, N. J. Tetrahedron: Asymmetry 1995, 6, 409. (b) Aldous, D. J.; Dutton, W. M.; Steel, P. G. Tetrahedron: Asymmetry 2000, 11, 2455.
(8) (a) Kozmin, S. A.; Rawal, V. H. J. Am. Chem. Soc. 1997, 119, 7165. (b) Taber, D. F.; Gorski, G. J.; Liable-Sands, L. M.; Rheingold, A. L. Tetrahedron Lett. 1997, 37, 631.

(9) Christl, M.; Huisgen, R. Chem. Ber. 1973, 106, 3345.

(10) Brown, H. C.; Kim, S. C. Synthesis 1977, 635.

(11) White, J. M.; Tunoori, A. R.; Georg, G. I. J. Am. Chem. Soc. 2000, 122, 11995.

(12) Crystal data for $(R, R)-\mathbf{1 0}: \mathrm{C}_{32} \mathrm{H}_{28} \mathrm{~N}_{2} \mathrm{O}_{2}, M=472.56$, monoclinic, space group $P 2{ }_{1}, a=13.4615$ (9) $\AA$, $b=10.5455$ (7) $\AA, c=17.8450$ (12) $\AA, \beta=101.0960(10)^{\circ}$, $V=2485.9(3) \AA^{3}, T=100 \mathrm{~K}, Z=4, \lambda\left(\mathrm{Mo} \mathrm{K}_{\alpha 1}\right)=0.71073$ $\AA, 30258$ reflections measured, 6046 unique $\left(R_{\text {int }}=0.0296\right)$ which were used in all calculations. The final $w R\left(F^{2}\right)=$ 0.0848 (all data). Full crystallographic data for this structure have been deposited with the Cambridge Crystallographic Data Centre as supplementary publication CCDC 265218. These data can obtained free of charge on application to CCDC, 12, Union Road, Cambridge CB2 1EZ, UK; fax: +44 (1223)336033; or e-mail: deposit@ ccdc.cam.ac.uk.

(13) Yang, S.; Hayden, W.; Griengl, H. Monatsh. Chem. 1994, $125,469$.

(14) Kamimura, A.; Omata, Y.; Kakehi, A.; Shirai, M. Tetrahedron 2002, 58, 8763.

(15) Crystal data for $(S)-\mathbf{2 3}: \mathrm{C}_{27} \mathrm{H}_{24} \mathrm{Cl}_{2} \mathrm{~N}_{2} \mathrm{O}_{2}, M_{r}=479.38$, orthorhombic, space group $P 2_{1} 2_{1} 2_{1}$ (no. 19), $a=6.2026$ (4) $\AA, b=15.5003$ (10) $\AA, c=24.4725$ (16) $\AA, V=2352.8$ (3) $\AA^{3}, T=173(2) \mathrm{K}, Z=4, \lambda\left(\mathrm{Mo} \mathrm{K}_{\mathrm{a} 1}\right)=0.71073 \AA$ A 14856 reflections measured, 5519 unique $\left(R_{\text {int }}=0.0311\right)$ which were used in all calculations. The final $w R\left(F^{2}\right)=0.0617$ (all data). Full crystallographic data for this structure have been deposited with the Cambridge Crystallographic Data Centre as supplementary publication CCDC 265219. These data can obtained free of charge on application to CCDC, 12, Union Road, Cambridge CB2 1EZ, UK; fax: +44 (1223)336033; or e-mail: deposit@ccdc.cam.ac.uk.

(16) Jae Nyong, K.; Eung, K. R. J. Org. Chem. 1992, 57, 6649.

(17) Nyerges, M.; Bendell, D.; Arany, A.; Hibbs, D. E.; Coles, S. J.; Hursthouse, M. B.; Groundwater, P. W.; Meth-Cohn, O. Synlett 2003, 947. 